\title{
The Propensity for Social Entrepreneurship During the Coronavirus Outbreak
}

\author{
Kartika Nuringsih, Nuryasman MN, and Rita Amelinda \\ Faculty of Economic \& Business, University Tarumanagara, Jakarta \\ Email: kartikan@fe.untar.ac.id; nuryasman@fe.untar.ac.id
}

\begin{abstract}
This research aims to explore scholarly the propensity for social entrepreneurship (PSE) under the condition of Coronavirus outbreak (Covid-19) and the large scale of social distancing in Jakarta, Indonesia. Entrepreneurial education is expected to encourage awareness of social problems among students. This research examines the relationship between perceived social supports and PSE. Additionally, it investigates the mediating effect of self-efficacy that links among empathy, moral obligation, and prior experience towards PSE. As many as 180 students filled the questionnaire through google forms during April $22-29^{\text {th }} 2020$. By using Smart-PLS proves a significant effect of perceived social support toward PSE and discovers the mediation effect on social entrepreneurial self-efficacy. The result shows a positive mindset on social entrepreneurship among students whereas this pandemic is as a trigger to intent in social entrepreneurship. It is a mechanism when understanding the social entrepreneurial education for students, thus leaders can utilize to improve regulation in the entrepreneurship learning program.
\end{abstract}

Keywords: social entrepreneurship, propensity, coronavirus outbreak.

\begin{abstract}
Abstrak: Penelitian ini bertujuan untuk mengeksplorasi secara ilmiah kecenderungan kewirausahaan sosial (KKS) dalam kondisi wabah Coronavirus (Covid-19) dan pembatasan sosial skala besar di Jakarta, Indonesia. Dengan pendidikan kewirausahaan diharapkan dapat mendorong kesadaran terhadap masalah sosial di kalangan mahasiswa. Penelitian ini menguji keterkaitan antara persepsi dukungan sosial dan KKS. Selain itu, menyelidiki efek mediasi pada efikasi diri yang menghubungkan empati, kewajiban moral, dan pengalaman sebelumnya terhadap KKS. Sebanyak 180 siswa mengisi kuesioner melalui google forms selama 22-29 April 2020. Dengan menggunakan Smart-PLS membuktikan adanya efek signifikan dukungan sosial yang dirasakan terhadap KKS serta menemukan efek mediasi efikasi diri pada kewirausahaan sosial. Hasil menunjukkan adanya pola pikir positif pada kewirausahaan sosial di kalangan mahasiswa sehingga pandemi ini menjadi pemicu niat pada kewirausahaan sosial. Hal ini sebagai mekanisme ketika memahami pendidikan kewirausahaan sosial pada mahasiswa, sehingga para pemimpin dapat memanfaatkan untuk meningkatkan regulasi dalam program pembelajaran kewirausahaan.
\end{abstract}

Kata Kunci: kewirausahaan sosial, kecenderungan, wabah coronavirus.

\section{INTRODUCTION}

Social entrepreneurship (SE) studies are relatively new compared with ecoentrepreneurship or sustainable entrepreneurship. In line with the education of sustainable 
development, studies of social entrepreneurship carried out including (Aure, 2018); (Ayob et al., 2013); (Chinchilla and Garcia, 2017); (Hockerts, 2017); and (Ip et al., 2017). The studies involved students by emphasizing psychological aspects as determinants of their interest in SE. Students as educated people are expected to be sensitive to the social problems so they can represent the millennial generation in perceiving of SE. Moreover, participation in SE is relatively lower compared with the commercial business startups (Aure et al., 2019). For these reasons, a study of the interest of entrepreneurship students is important to be explored to the extent that this education is able to form a balance with social goals.

Practically, the business approach emphasizes economic goals rather than social goals. Aligning with sustainable development, the business activities should create and sustain the social values or known as social entrepreneurship. It is categorized into two kinds, namely: non-profit organizations (NPOs) and social enterprises. Through the market orientation, this income can be used to meet the sustainability of social organization (Defourny and Kim, 2011). In addition, social enterprises combine economy and social values with a mission to overcome social problems (Dacin et al., 2011). Through education is expected to improve social knowledge so that it can inspire entrepreneurship students for aligning with profit and people orientations.

Basically, the role of SE is aimed at overcoming social problems e.g., poverty alleviation, health care, environmental preservation, education and training, and advocacy and campaigning human rights. However, along with the pandemic of Coronavirus (Covid19), the impact of this outbreak had destroyed various aspects of people's lives. No limited on the healthies, it has disrupted the stability of economic and shifted the educational and social-cultural activities. Since being detected in Wuhan China at the end of 2019, this outbreak had rapidly spread throughout the world, including Indonesia. Hence, the World Health Organization declares as a global pandemic. It spreads so quickly that the number of sufferers and the victim is more increasing. Fig. 1 shows in Indonesia the impact of this outbreak reached 10.118 cases with the number of people dying as many as 792 cases on April $30^{\text {th }}, 2020$. The number of cases is increasing massively in other provinces. The escalation of cases has a psychological impact on society and affects a person's perspective toward social problems.

Figure 1. The Number Cases of Coronavirus Outbreak

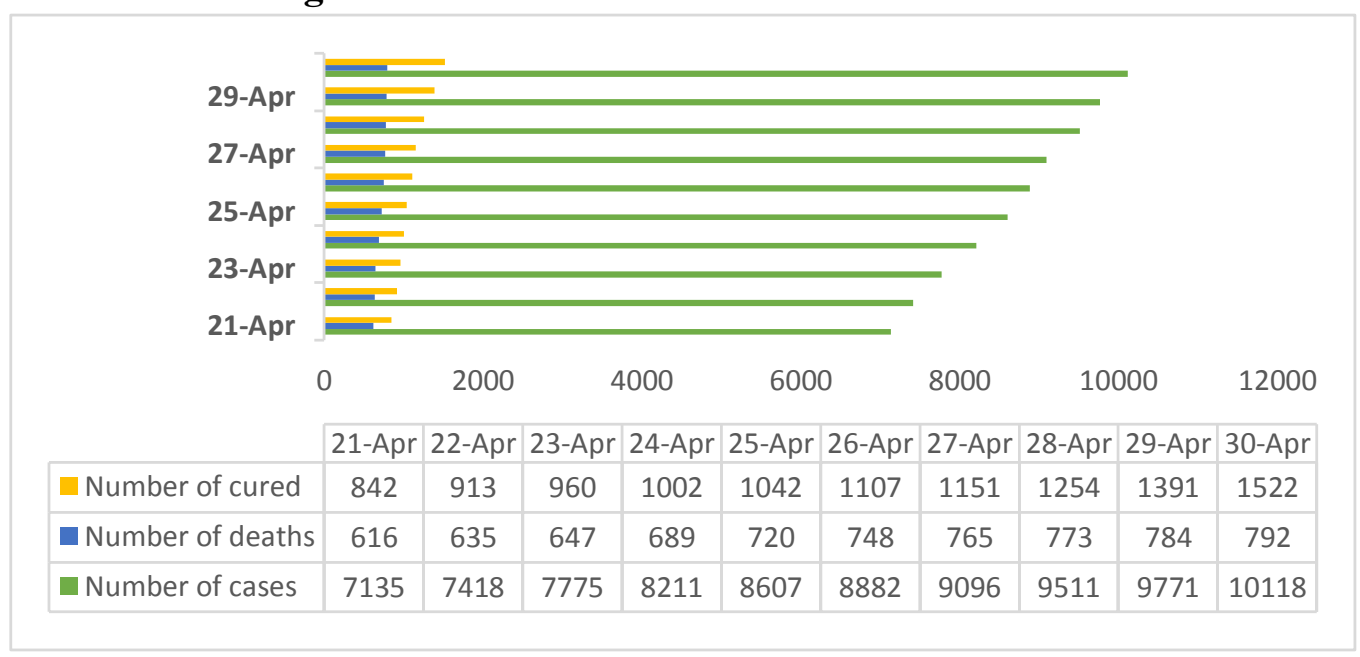


Moreover, the large-scale social distancing policy requires the work from home so that it impacts the fulfillment of the economic needs at the grassroots level. Macroeconomic growth is not in line with expectations so that the lower middle class is affected by this condition. This crisis can be diminished through social awareness in facing the Covid-19 pandemic. Social solidarity anticipates the problems of society. Therefore, the role of entrepreneurs in overcoming socio-economic problems become important.

Although, this research is not directly related to the Covid-19 protocol, through the social entrepreneurial studies provide valuable insights for entrepreneurs or philanthropists in dealing with pandemic problems. This study explores scholarly the psychological aspects of students in perceiving this outbreak toward social enterprises. This interest relates to the desire to place social value as part of the business practices. This research considers previous studies, even with a background outside of the pandemic. The study of (Ayob et al., 2013) proved the impact of empathy toward perceived feasibility in Malaysia. (Chinchilla and Garcia, 2017) noted the effect of mindfulness orientation on social, volunteering experience, and entrepreneurship training in Mexico. (Hockerts, 2017) emphasized empathy, moral obligation, self-efficacy, perceived social support, and experience in Scandinavian students. (Aure, 2018) placed the big five personality traits as a predictor of the intention. Further, (Ip et al., 2017) examined Hockerts's model involving high school students in Hong Kong. These variables are as antecedents of social entrepreneurial intention. Learning with the outbreak, the study explores the social behavior of entrepreneurial students in perceiving SE as a way to realize social solidarity to the community in the current and future.

Relevant with the prior studies, five variables are involved to predict propensity for social entrepreneurship (PSE) under pandemic background. The antecedent consists of (1) empathy (Ayob et al., 2013; Hockerts, 2017; Ip et al., 2017), (2) moral obligation; (3) social entrepreneurial self-efficacy; (4) perceived social support, and (5) prior experience (Hockerts, 2017; Ip et al., 2017). The mechanism is as follows: First, in overcoming the outbreak requires high awareness among communities and entrepreneurs. This condition encourages the human's interesting to social enterprises. The theory of planned behavior (TPB) is a usable frame to explain the formation of entrepreneurial intention (Aure et al., 2019). In line with TPB (Ajzen, 1991) that self-efficacy has a positive impact on intention. Likewise, the perceived social support is also a determinant of intention that reflects the social norms. Second, the model places self-efficacy as a mediating variable. One of the obstacles of students in realizing business start-up is caused by the lack of self-efficacy. This variable is important to be observed in entrepreneurship education studies. For this reason, it mediates the link between empathy, moral obligation, and prior experience to PSE. Based on (Hockerts, 2017) empathy and moral obligation represent the psychological aspects that can foster the self-confidence of students in creating SE. Likewise, prior experience in social activities can strengthen self-efficacy among students so that they will be more interested in SE. Thus, it is used to analyze the student's propensity on social entrepreneurial which is triggered by the pandemic of Covid-19.

Understanding during the outbreak and the large-scale social restrictions are expected as inspiration to be social entrepreneurs. This perspective can form the social behavior of students to concern about social problems. The theoretical basis for building a research framework refers to TPB, although the description involves the entrepreneurial event model (Shapero and Sokol, 1982) and the entrepreneurial potential models (Krueger, 1993). Finally, the study goals to examine the relation of self-efficacy and social support toward social 
propensity and to explore the role of mediating effect of social entrepreneurial self-efficacy to link empathy, moral obligation, and prior experience to PSE. Moreover, it also analyzes the impact of social support toward social propensity. The result serves as information for the leader of management program to perfect the learning program for entrepreneurial students. Thus, it can be utilized to foster the social entrepreneurial self-efficacy on students.

\section{THEORETICAL REVIEW}

Definition of social entrepreneurship. The scholarly articles about SE began to be discovered easily after in the 2000s. These were in line with the declaration of Millennium Development Goals (MDGs) by the United Nation in 2000. There are some targets such as health, alleviating poverty, gender equality, environmental, HIV/AIDS to a global partnership. These targets can be mapped into three aspects namely: economic, social, and environmental, or familiarly referred to as the triple bottom line. Efforts to synergize these aspects require the support of entrepreneurs or business owners so that their orientations are not limited to economic but balanced by social or ecological value. Thus, understanding of $\mathrm{SE}$ is defined from the initial concept to its relevance to the goals of a global society.

The initial definition is explained through the statement of (Dees, 1998) that SE is one a kind of entrepreneurship, thus the character of social entrepreneur as follows: (1) as change agents with a mission-focused not only on private value but also on social value, (2) recognizing opportunities based on this mission, (3) using continuous innovation, adaptation, and learning in this recognition process, (4) act boldly while also being accountable. In this definition, there is one special character that is as an agent of change. Similar with before, (Peredo and McLean, 2006) noted that SE is exercised by some person or group with criterion as follow: (1) aim at creating social value, (2) show a capacity to recognize and take advantage of opportunities, (3) continuously engaging of innovation, (4) willing to accept an above-average degree of risk in creating social value, and (5) unusually resourceful or undaunted to get resources in pursuing the social venture. To this definition, the author adds a risk-taking factor that must be faced by social entrepreneurs.

Further understanding looks at the improvement in defining of SE. In line with the ebook of Social Entrepreneurship which published by Palgrave Macmillan in 2006, some definitions are elaborated as follow:

"SE is an innovative, social value-creating research activity that can occur within or across the nonprofit, business, and public sectors" (Austin, 2006).

"A quite general working definition of SE: a set of institutional practices combining the pursuit of financial objectives with the pursuit and promotion of substantive and terminal values" (Cho, 2006).

"As the innovative use of to create a social venture are formed resource combinations to pursue opportunities aiming at the creation of organizations and/or practices that yield and sustain social benefits" (Mair \& Noboa, 2006).

"Social purpose business ventures are hybrid enterprises purpose business ventures straddling the boundary between the for-profit business world and social mission-driven 
public and nonprofit organizations" (Hockerts, 2006).

"SE as a process that includes: (1) the identification of a specific social problem and a specific solution (or set of solutions) to address it, (2) the evaluation of the social impact, the business model and the sustainability of the venture, and (3) the creation of a social mission-oriented for-profit or a business-oriented nonprofit entity that pursues the double (or triple) bottom line" (Robinson, 2006).

These various definitions can be used to understand the character and role of SE in student's versions so that through this role they can contribute to cope with the social problem or synergize in creating social welfare. Even, in line with sustainable development, their role can contribute to achieving the goals of sustainable development.

Developing the Hypothesis of Propensity for Social Entrepreneurship. This model frames the determinant of the propensity for SE which is inspired by prior studies. (Koe, et al., 2014; 2015) placed the term of propensity to illustrate the intention, therefore the same framing used in this study. For this reason, the term propensity is a synonym of intention. Thus, according to (Bird, 1988) intention is defined: the state of mind directing a person's attention and actions toward a specific object (goal). Generally, it shows the situation or human mind to decide for becoming an entrepreneur through direct experience, attention, and action to entrepreneurial activities. Related to the SE shows the intention or desire to involve social value in the economic goals. Studying intentional behavior can know the reason for an entrepreneur to be interest (or not) in overcoming social problems. Expected during pandemic becomes a trigger for students and forms a mindset toward SE so that impact on her or his behavior to be aware of social problems. Therefore, the theoretical background bases on the theory of plan behavior from (Ajzen, 1991) while in elaborating the result involves the entrepreneurial event model (Shapero and Sokol, 1982) and entrepreneurial potential model (Krueger, 1993). Relevant to prior studies are deployed the frame of the study such as follow:

Social entrepreneurial self-efficacy is regarded as 'a person's belief that individuals can contribute toward solving societal problems' (Hockerts, 2017). In line with TPB, the perceived self-efficacy is analogized as perceived behavioral control which is an antecedent of intention. Self-efficacy is related to the ability to get resources and manage the business well. With the Covid-19 pandemic, it encourages self-confidence where one day it will be interested in SE or engaged with NPOs in alleviating social problems. The first hypothesis:

H1: Social entrepreneurial self-efficacy is positively related to the propensity for social entrepreneurship.

Perceived Social Support is a form of support for social ventures, including social capital. Social support is provided in the form of material and motivation or enthusiasm provided by the closest environment such as friends, family, or community. In line with TPB, perceived social support is analogous to the social norms, which is an antecedent of intention. In the non-social entrepreneurship study, Turker \& Sonmez Selcuk, (2009) introduced the entrepreneurial support model which placed the relation support as the antecedent of 
entrepreneurial students' intention. In SE, these factors are needed in ensuring intentions. Moreover, in the pandemic of Covid-19 and the conditions of social distancing are perceived as social solidarity in facing the pandemic, thus they have desire in SE. The second hypothesis:

H2: Perceived social support is positively related to the propensity for social entrepreneurship.

According to the entrepreneurial potential model (Krueger, 1993), a number of exogenous factors that are personal and situational affect the perceived social norm and perceived self-efficacy then form the perceived feasibility which ultimately affects the intention. Meanwhile, according to (Shapero and Sokol, 1982), the perceived feasibility is how an individual believes in his or her capability of starting an entrepreneurial venture. Thus this variable is identical to the perceived behavioral control in TPB. Based on this reason, the social entrepreneurial self-efficacy places as mediating variable to link between empathy, moral obligation, and prior experience to social entrepreneurial intention.

Empathy is defined as sharing and recognizing the same feelings experienced by other people (Decety and Jackson, 2004). Emotional empathy is the vicarious sharing of other's feelings (McDonald and Messinger, 2011; Smith, 2006). Empathy is the key to social ventures in understanding customer needs or creating customer satisfaction. Associated with the Covid-19 pandemic, the existence of a feeling of fate in the face of a pandemic will open one's conscience so that it is motivated to engage in social action which ultimately forms an interest in social entrepreneurial intention. For these reasons, the third hypothesis as follow:

H3: Social entrepreneurial self-efficacy as a mediating variable to link empathy to the propensity for social entrepreneurship.

Moral obligation is an expression of a sense of responsibility towards social problems. Having a strong moral obligation can influence social awareness and responsibility thereby increasing pro-social intentions and behavior (De Groot and Steg, 2009). Moral obligation is 'a decision-making sub process that occurs after an individual makes moral judgment and prior to establishing a moral intention' (Haines et al., 2008). By having a moral obligation, a person feels that he is partly responsible for social problems means that he is attached to his self-confidence in social ventures so that intentions can be formed. An extraordinary event caused by the Covid-19 pandemic carries moral responsibility so that it fosters confidence and ultimately has a potential effect on social entrepreneurial intention. Based on this mechanism, the fourth hypothesis as follows:

H4: Social entrepreneurial self-efficacy as a mediating variable to link moral obligation to the propensity for social entrepreneurship.

Prior Experience is indispensable for entrepreneurs. In general, prior or direct experience greatly influences business success. According to (Hockerts, 2017) prior experience with social problems is regarded as people's practical experience in working with social-sector organizations, which can generate familiarity with such types of social problems. According 
to Shumate, (Atouba et al., 2014) experience helps social entrepreneurs understand the success and failure factors before engaging in new business. In addition, it can identify role models and develop self-confidence in building a company. Being accustomed to dealing with social problems, carrying out social actions, or collaborating with social institutions can enhance experience and abilities in networking so as to increase self-confidence. This condition can increase interest in SE. For these reasons, the last hypothesis as follow:

H5: social entrepreneurial self-efficacy as a mediating variable to link prior experience to the propensity for social entrepreneurship.

\section{METHODOLOGY}

Fig. 2 depicts the stages of the research methods. First: the study population consisted of active students in the Management program at Tarumanagara University in West Jakarta. This institution has a vision as an entrepreneurial university with entrepreneurship education given generally to students. This program also organizes the learning of social entrepreneurship. The sample selection method uses a random sampling technique. Respondents came from various regions in Indonesia, the majority come from the red zones in Greater Jakarta such as Jakarta, Tangerang, Bekasi, Depok, and Bogor. The number of respondents as many as 180 students.

Figure 2. Research Stages

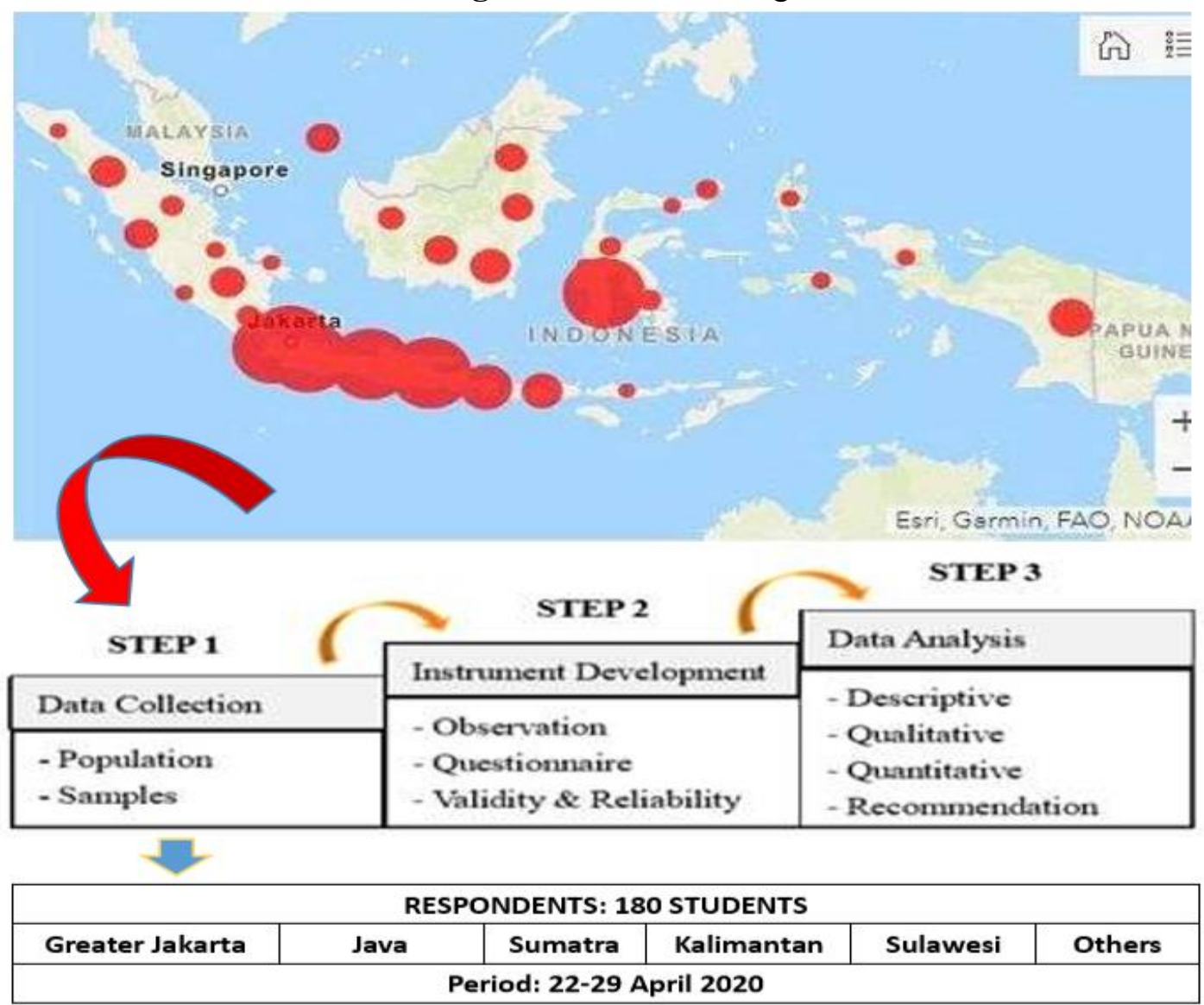


Second: the indicators are developed from prior studies with a total of 18 items. To measure the PSE is adopted from social entrepreneurial intention questionnaire in (Aure et al., 2019); (Hockerts, 2017) while the indicator of empathy, moral obligation, prior experience, selfefficacy, and perceived social support are adopted in (Aure et al., 2019); (Hockerts, 2017); (Ip et al., 2017). In this study using the propensity to describe students' interest in social entrepreneurship. The term propensity refers to research by (Koe et al., 2014: 2015) that use propensity as a synonym of intention. Therefore, in explaining the results, both are used interchangeably. The data was collected through an online questionnaire distributed via Google form during the period of large-scale social restrictions in Jakarta on April 22-29 $9^{\text {th }}$ 2020. Questionnaires were distributed to respondents and filled out by the respondents themselves. They were asked to choose one option from 1 (very not agree) up to 5 (very agree). Testing the validity and reliability is done to ensure the quality of the data from respondents. The reliability testing refers to Cronbach alpha and composite reliability while the validity uses outer loading, cross-loading, and t-statistical value.

Third: the data analysis method uses descriptive, qualitative, and quantitative approaches. Smart-PLS is used to identify reliability in the inner and outer models. At this stage, the five hypotheses are tested using a one-tailed t-test. Thus, the results can be used as recommendations for management study programs to improve the entrepreneurial learning model, especially in motivating students in social entrepreneurship.

\section{THE RESULTS OF STATISTICAL TESTS}

The profile of respondents are as follows: respondents consist of four concentration studies on Management program such as entrepreneurship, financial management, marketing management, and human resources management. Fig. 3 illustrates the majority of respondents from entrepreneurship (33\%), 29\% from financial management, $22 \%$ from human resource management, and 16\% from marketing. Although different concentrations, all students get a course in the basics of entrepreneurship. Meanwhile, social entrepreneurship is the chosen subject for all concentrations.

Figure 3. Distribution of concentration studies

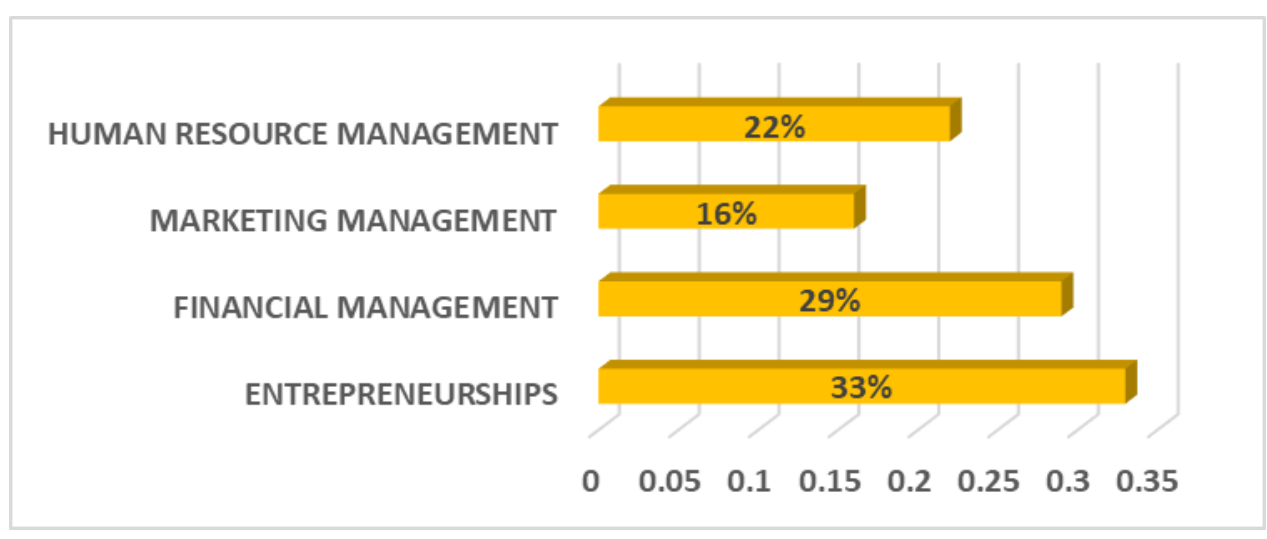


Fig. 4 depicts the majority of the respondent is male students $(53 \%)$ while as many as $47 \%$ is female students. Most of the respondents came from Greater Jakarta (74\%), while others came from several cities in Java, Sumatra, Kalimantan, and Sulawesi. There are a small number of students from Maluku, Bali, East Nusa Tenggara, and Papua. The majority of respondents are in the red zones, thus forming the same feeling and moral obligation due to the impact of this outbreak. However, as many as $14 \%$ of respondents stated as active social cooperation with outsiders through student activity units, religious institutions, or foundations, while $86 \%$ stated they were not actively involved in social activity. Besides that, $18 \%$ of respondents said they had held social activities in the last 3 months whereas $82 \%$ stated otherwise. However, this outbreak affects psychological aspects, thereby encouraging interest in social entrepreneurship.

Figure 4. The Profile of respondents

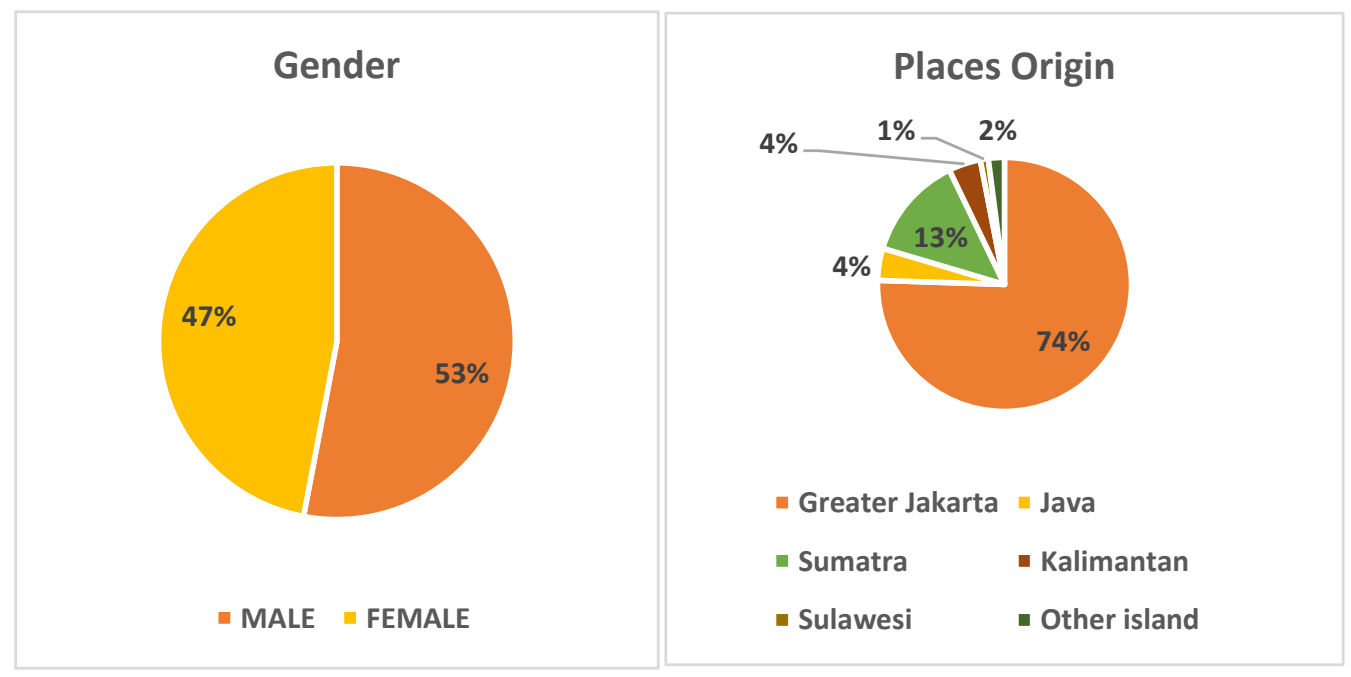

British Council \& UNESCAP, (2018) noted over $75 \%$ of social enterprises in Indonesia are dominated by young leaders, where the majority $(46 \%)$ are between the ages of 25-34 years old. It is suitable for students. Therefore, their perception can be used by the institution to enhance social events and to align students' mindset in building startups. The introduction of the role and real contribution of social enterprises needs to be done through seminars so that the theme of the seminar is not limited to the economic value as the basis for creating a competitive advantage. It is necessary to develop the students' thinking on social value or environmental value. In line with sustainable development, one of the bottom lines is the social goal. This relates to students' design thinking of profit and social value as a unity of purpose in business activities.

Table 1-2 show the validity of all indicators higher than 0.70 . Based on the result of outer loading and cross-loading are found one indicator (PSE3) is not valid so it is ignored from the instruments of PSE. Thus, a total of 17 indicators. Furthermore, reliability testing shows the composite reliability values over 0.80 . The indicator test results are as follows: 
Table 1. Indicator of Propensity For Social Entrepreneurship (PSE)

\begin{tabular}{llll}
\hline Code & Indicators & Validity \\
\cline { 2 - 3 } & Cronbach's Alpha: 0,621; Composite Reliability: 0,839 & \\
\hline PSE1 & $\begin{array}{l}\text { I hope that someday after new normal condition I can get involved in } \\
\text { organizations that aim to overcome social problems }\end{array}$ & 0,824 \\
\hline PSE2 & $\begin{array}{l}\text { I have an idea to start a social business so that I can overcome the problems of } \\
\text { society in the future }\end{array}$ & 0,877 \\
\hline
\end{tabular}

However, this research is a preliminary study of social entrepreneurial intention by using the Covid-19 pandemic as a background. For this reason, the instrument refers to (Aure et al., 2019; Hockerts, 2017) involving 3 indicators. Instead, do not adopt the indicators in (Ip et al., 2017) which uses 8 items. This is to anticipate the bias of respondents' assessment of the choice of more indicators. The Cronbach's alpha of PSE is lowest among constructs. However, the value of composite reliability is 0.839 so it meets the reliability standard. Because of this result, to ensure the accuracy of the conceptual measurement scale is used the information from composite reliability. This agrees with Werts et al. cited by (Henseler et al., 2009) that the composite reliability is more appropriate to test internal consistency or construct reliability than Cronbach's Alpha because the value of Cronbach's Alpha has a tendency to be higher or lower than the estimate. The overall results are as follows:

Table 2. Indicator of Independent Variables

\begin{tabular}{|c|c|c|}
\hline \multirow[b]{2}{*}{ Code } & Indicators & \multirow[b]{2}{*}{ Validity } \\
\hline & $\begin{array}{l}\text { Empathy (EMP) } \\
\text { Cronbach's Alpha: 0,808; Composite Reliability: 0,885 }\end{array}$ & \\
\hline EMP1 & $\begin{array}{l}\text { I feel compassion for the condition of the people affected by the social } \& \\
\text { economic impact of the Covid-19 pandemic }\end{array}$ & 0,765 \\
\hline EMP2 & $\begin{array}{l}\text { When thinking about the state of society being affected by the pandemic of } \\
\text { Covid-19, I try to help to ease the burden of his life }\end{array}$ & 0,884 \\
\hline EMP3 & $\begin{array}{l}\text { Seeing the condition of the medical team and the community affected by the } \\
\text { pandemic of Covid-19, triggered my emotions to help them }\end{array}$ & 0,891 \\
\hline Code & $\begin{array}{l}\text { Moral Obligation (MOB) } \\
\text { Cronbach's Alpha: 0,823; Composite Reliability: 0,894 }\end{array}$ & Validity \\
\hline MOB1 & $\begin{array}{l}\text { We are morally obliged to help others who are facing social \& economic } \\
\text { problems due to the Covid- } 19 \text { pandemic }\end{array}$ & 0,849 \\
\hline MOB2 & $\begin{array}{l}\text { It is an ethical responsibility to help people who are less fortunate because of } \\
\text { the Covid-19 pandemic }\end{array}$ & 0,894 \\
\hline MOB3 & $\begin{array}{l}\text { Social justice requires that we help others who are facing the Covid-19 } \\
\text { pandemic problem }\end{array}$ & 0,835 \\
\hline Code & $\begin{array}{l}\text { Social Entrepreneurial Self-Efficacy (SESE) } \\
\text { Cronbach's Alpha: 0,796; Composite Reliability: } 0,880\end{array}$ & Validity \\
\hline SESE1 & $\begin{array}{l}\text { I am convinced that I am personally confident that I can contribute to } \\
\text { overcoming social problems, if I focus on those problems }\end{array}$ & 0,849 \\
\hline SESE2 & I could figure out a way to help solve the problems that society faces & 0,846 \\
\hline SESE3 & $\begin{array}{l}\text { Among us can contribute to solving social problems that are being faced by } \\
\text { society }\end{array}$ & 0,833 \\
\hline Code & Perceived Social Support (SEPS) & Validity \\
\hline
\end{tabular}




\begin{tabular}{lll}
\hline & Cronbach's Alpha: 0,863; Composite Reliability: 0,916 & \\
\hline SEPS1 & $\begin{array}{l}\text { People will be willing to support me if I want to start an organization or activity } \\
\text { to help socially marginalized people. }\end{array}$ & 0,913 \\
\hline SEPS2 & $\begin{array}{l}\text { If I seriously plan to overcome social problems, people are willing to support } \\
\text { me. }\end{array}$ & 0,870 \\
\hline SEPS3 & $\begin{array}{l}\text { It is very possible for me to invite volunteers or donors to realize activities to } \\
\text { overcome social problems }\end{array}$ & 0,874 \\
\hline Code & $\begin{array}{l}\text { Prior Experience (PEX) } \\
\text { Cronbach's Alpha: 0,896; Composite Reliability: 0,936 }\end{array}$ & Validity \\
\hline PEX1 & I have experience working on social problems & 0,911 \\
\hline PEX2 & I have volunteered or worked with social organizations & 0,921 \\
\hline PEX3 & I know a lot about social organizations & 0,899 \\
\hline
\end{tabular}

The t-statistical outer model test is used to perfect previous validity testing. Table 3 shows the value of t-statistic consistently with both criteria of validity testing. The majority of direct paths result in the high value of the original sample. Conversely, the paths produce a low standard deviation. Thus, the entire direct paths generate a higher value of the tstatistic. Therefore, it can be concluded that the entirety of paths are significant condition so that every indicator are valid to measure each construct.

Table 3. The T-Statistical Outer Model

\begin{tabular}{|c|c|c|c|c|c|}
\hline Direct Path & $\begin{array}{c}\text { Original } \\
\text { Sample } \\
\text { (O) }\end{array}$ & $\begin{array}{c}\text { Sample } \\
\text { Mean } \\
\text { (M) }\end{array}$ & $\begin{array}{l}\text { Standard } \\
\text { Deviation } \\
\text { (STDEV) }\end{array}$ & $\begin{array}{l}\text { Standard } \\
\text { Error } \\
\text { (STERR) }\end{array}$ & $\begin{array}{c}T \\
\text { Statistics } \\
(\mid \mathbf{O} / \text { STERR } \mid)\end{array}$ \\
\hline EMP1 <- EMP & 0,765 & 0,761 & 0,064 & 0,064 & 11,984 \\
\hline EMP2 <- EMP & 0,884 & 0,880 & 0,037 & 0,038 & 22,902 \\
\hline EMP3 <- EMP & 0,891 & 0,895 & 0,029 & 0,028 & 31,281 \\
\hline MOB1 <- MOB & 0,849 & 0,851 & 0,036 & 0,035 & 23,927 \\
\hline $\mathrm{MOB} 2<-\mathrm{MOB}$ & 0,894 & 0,893 & 0,024 & 0,024 & 36,518 \\
\hline MOB3 <- MOB & 0,835 & 0,835 & 0,049 & 0,049 & 16,926 \\
\hline PEX1 <- PEX & 0,911 & 0,910 & 0,027 & 0,027 & 34,039 \\
\hline PEX2 <- PEX & 0,920 & 0,917 & 0,029 & 0,029 & 31,464 \\
\hline PEX3 <- PEX & 0,899 & 0,899 & 0,026 & 0,026 & 34,148 \\
\hline PSE1 <- PSE & 0,824 & 0,820 & 0,066 & 0,066 & 12,422 \\
\hline PSE2 <- PSE & 0,877 & 0,877 & 0,034 & 0,034 & 26,006 \\
\hline SEPS1 <- SEPS & 0,913 & 0,910 & 0,021 & 0,021 & 42,483 \\
\hline SEPS $2<-$ SEPS & 0,870 & 0,865 & 0,042 & 0,042 & 20,530 \\
\hline SEPS3 <- SEPS & 0,874 & 0,873 & 0,034 & 0,034 & 26,009 \\
\hline SESE1 <- SESE & 0,849 & 0,853 & 0,031 & 0,031 & 27,720 \\
\hline SESE2 <- SESE & 0,846 & 0,837 & 0,055 & 0,055 & 15,352 \\
\hline SESE3 <- SESE & 0,833 & 0,831 & 0,045 & 0,045 & 18,714 \\
\hline
\end{tabular}

Under the condition of the outbreak and the large-scale social distancing in Jakarta, 
so the result of bootstrapping is summarized in Fig. 5. The path analysis among variables is as follows: Firstly, the path coefficient between SESE and PSE produces a statistical t value of 1.566. By using a one-tailed t-test, it is higher than 1.282 so that self-efficacy significantly predicts the PSE at 10\%. The result proves the first hypothesis (H1) is not rejected. Secondly, the path coefficient shows the relationship between social support and PSE. The $t$-value of statistics is 3.561 which is bigger than 1.645 so that it has a significant effect at the level of $5 \%$. It means the second hypothesis (H2) is accepted. Thirdly, the path coefficient between empathy and SESE shows a statistical value of 1.555 so that it is significant at the level of a $10 \%$ one-tailed t-test. It proved the third hypothesis $(\mathbf{H 3})$ is not rejected. Fourthly, the path coefficient between moral obligation and SESE shows a statistical value of 2.989 so that it is significant at the level of 5\%. The result shows the fourth hypothesis (H4) is accepted. Lastly, the path coefficient between prior experience and SESE identifies a statistical t-value of 3.737 so that significant at 5\%. It proves the fifth hypothesis (H5) is accepted. These results indicate that self-efficacy is an obstacle for students so it needs to be a priority in entrepreneurial education.

Figure 5. Bootstrapping Results

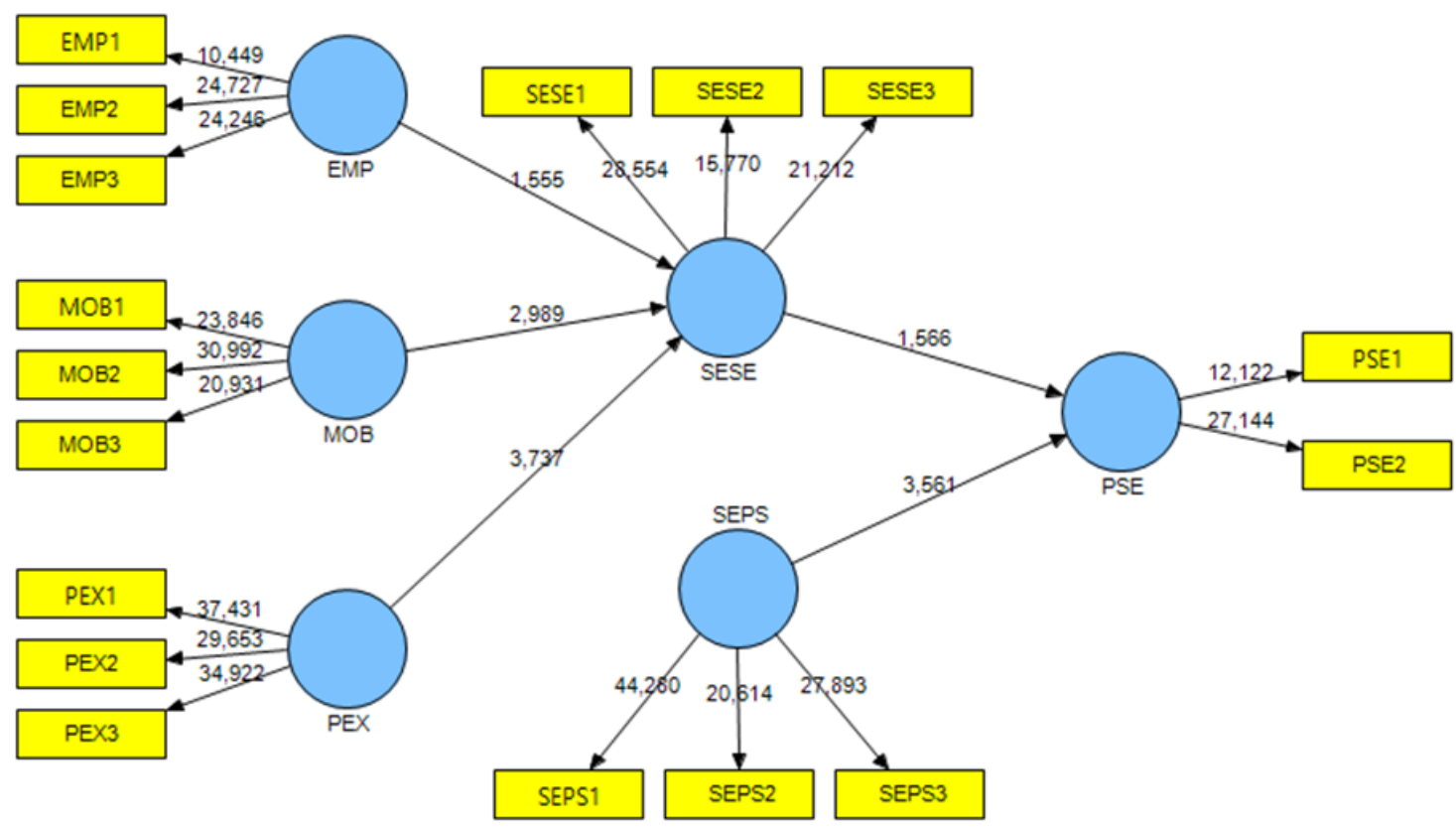

Further, Table 4 summarizes the influence of each construct in the model of PSE. Firstly the SESE construct directly affected PSE by $9.16 \%$ while the SEPS contract has an effect on PSE of $23.99 \%$. The SESE represents the self-efficacy in running the social entrepreneurship. Generally, the majority of students own some obstacles related to selfconfidence in creating a new venture. Indeed, students require a high self-efficacy in starting a social enterprise. Cause of the reason, this behavior makes the lower impact of the selfefficacy to the intention. Conversely, this is different from SEPS which represents social support for social ventures. The majority of students perceive that social support is more easily obtained from stakeholders or jointly with philanthropists. Therefore, the perceived 
social support is most significant in forming the propensity for social entrepreneurship. Hence, both contributed $33.10 \%$. This is equal to the value of $\mathrm{R}^{2}$ on PSE. The value of $\mathrm{R}^{2}$ is 0.331 which means approximately $33.10 \%$ of PSE is determined by this model while $66.90 \%$ is formed by other factors.

Table 4. Percentage of Influence between Constructs

\begin{tabular}{lccc}
\hline \multicolumn{1}{c}{ Path } & \multicolumn{2}{c}{ Effect } & Total \\
\cline { 2 - 3 } & Direct & Indirect & \\
\hline EMP $>$ SESE & 0,098434 & - & 0,098434 \\
\hline MOB $>$ SESE & 0,191771 & - & 0,191771 \\
\hline PEX $>$ SESE & 0,135231 & - & 0,135231 \\
\hline EMP $>$ PSE & - & 0,020210 & 0,020210 \\
\hline MOB $>$ PSE & - & 0,032676 & 0,032676 \\
\hline PEX $>$ PSE & - & 0,023194 & 0,023194 \\
\hline SEPS $>$ PSE & 0,239852 & - & 0,239852 \\
\hline SESE $>$ PSE & 0,091643 & - & 0,091643 \\
\hline
\end{tabular}

Secondly: the mediating test of SESE is produced as follows: (1) the influence of EMP at $9.84 \%$, (2) the influence of the MOB of $19.18 \%$, and (3) the effect of PEX at $13.52 \%$. Empathy (EMP) is the ability to understand the feelings of others. Basically, in the condition of the Covid-19 outbreak, people empathize with the effects of a pandemic. However, it is not strong enough to encourage self-efficacy toward social entrepreneurial. Therefore, the impact of empathy tends to be the lowest compared to the other two constructs in forming self-efficacy for social entrepreneurial. On the contrary, moral obligation (MOB) has the strongest effect on self-efficacy. Moral obligation is an expression of a sense of responsibility towards social problems so that under the outbreak people obligate morally to help each other in overcoming the problems. The Covid-19 pandemic carries moral responsibility so that it fosters self-confidence among students. Finally, the prior experience (EXP) has a greater effect on self-efficacy, although it is relatively lower than a moral obligation. This shows that the experience of students in dealing with social problems and having collaborated with social organizations or communities are very useful for encouraging self-efficacy.

Thus, the total contribution is $42.50 \%$ or equal to $R^{2}$ of SESE. The value of $R^{2}$ is 0.425 which means approximately $42.50 \%$ of SESE is determined by three factors while $67.50 \%$ is formed by other factors. Furthermore, the three constructs e.g., empathy, moral obligation, and prior experience contributed indirectly to the propensity for social entrepreneurship with a value of $2.02 \% ; 3.27 \%$, and $2.32 \%$. These prove the lower impact result of empathy compared with other constructs namely moral obligation and prior experience.

\section{DISCUSSION}

Fig. 6 depicts that perceived social support produces the highest of the original sample and mean. Then, it is followed by moral obligation and prior experience. These results give a strong influence on the PSE. Contrarily, empathy and self-efficacy produce the lowest of the original sample and mean value. In this model, both are significant at a $10 \%$ one-tailed 
t-test. The lowest standard deviation is on the prior experience while the biggest on the selfefficacy on social entrepreneurship.

Figure 6. Path Coefficient of PSE

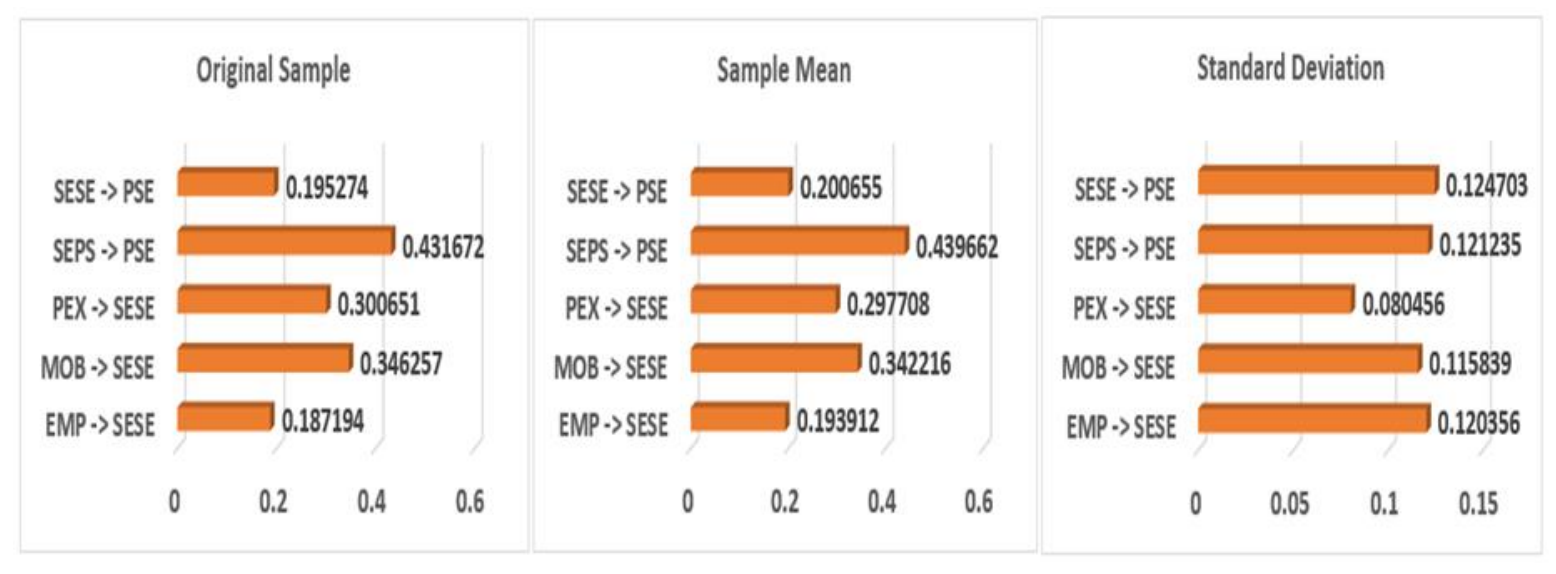

Although at the level of $10 \%$, the link between social entrepreneurship self-efficacy and PSE has proven to be significant. Related to TPB, (Ajzen, 2002) stated that the term of perceived behavioral control and self-efficacy are quite similar. Both are concerned with the perceived ability to perform a behavior. Further, the social entrepreneurial self-efficacy is regarded as "a person's belief that individuals can contribute toward solving societal problems" (Hockerts, 2017). This condition is related to the ability to get resources, networking, and managing the social venture. In line with social entrepreneurial studies, this behavior is appropriate with the prior researches such as (Aure et al., 2019); (Ayob et al., 2013); (Hockerts, 2017); and (Tiwari et al., 2017). Thus, self-efficacy is antecedent to understand students' interest in social entrepreneurship.

Actually, in the pandemic of Covid-19 and the condition of large-scale social distancing are able to foster the self-confidence of students so that they have a desire in social enterprises or jointly a social institution. As solidarity in overcoming the Covid-19 pandemic, institutions organized a social campaign for humanity. The activity was carried out by involving volunteer medical teams and health equipment, helping people affected by the economic impact of the pandemic, and Covid-19 educating through online media, newspapers, and television on a national scale. These practices are able to encourage the sense of care for humanity, thus this moment fosters the self-efficacy among students to be intent in the social entrepreneurial.

In a new normal period after the outbreak, the institution ought to increase the knowledge and practice through student projects based on social enterprises. It is done to improve the students' confidence. In learning entrepreneurship, there is an association between students' knowledge of cognition and intention to be entrepreneurs (Pihie et al., 2013), thus some agendas must be utilized to increase knowledge and its implementation for students. For instance: seminar events can be used to present mentors from non-profit organizations or social enterprises such as Gibran Hufaizah as CEO e-Fishery, Vikra Ijaz as Chief Product Officer at Kitabisa.com, Yohanes Sugihtononugroho as CEO Crowde, or Maximus Tipagau as an initiator of flying doctors in Papua. Their story is an insight into developing social entrepreneurship. Further, the coaching is arranged to introduce the new 
knowledge e.g., product development, market analysis, business innovation, sustainability scheme, growth planning, measurement and assessment, finance, investment, and others. By the knowledge, students will have more ability particularly in recognizing opportunities, engaging innovation, and calculating risk in pursuing the social venture. These matters are in line with previous kinds of literature e.g., (Peredo and McLean, 2006); (Shaw and Carter, 2007). Indeed, students will be more interested in social enterprises in the future.

Moreover, the relationship between perceived social support and PSE is the strongest significant. It is suitable with the previous of social entrepreneurial studies e.g., (Aure et al., 2019); (Ayob et al., 2013); (Hockerts, 2017); (Ip et al., 2017). Perceived social support is a form of support for social ventures, including social capital. This capital can be obtained by socio entrepreneurs through social networking, personal relationships, and maintaining trust and a good reputation. In line with TPB, the perception of social support is identical to the social norms so that it becomes an important antecedent to understanding the intention. Students perceive the support of various parties during overcoming the pandemic problems, including from their peers and family members or communities. This condition is related to cultural aspects. It is relevant to Hofstede's theory that Asian culture tends to be collective rather than individualist. This character forms an entrepreneurial culture that tends to be collective. Thus, social support becomes the most significant. In addition, information technology accelerates a person in providing sympathy or solutions to social problems, especially in overcoming the pandemic. Based on these results, the institution ought to foster this potential by collaborating with stakeholders who respect the social solution.

British Council is one of the stakeholders which promotes the growth of social enterprise and impact investment across the Asia-Pacific region. The program relates to the progress of sustainable development goals (SDGs). Moreover, Indonesia presents specific opportunities for social enterprises such as creative industries, agriculture and fisheries, healthies, educations, and others. Meanwhile, specifically in Indonesia, a study of (Pratono et al., 2016) noted four types of social enterprises. The mapping consists of an entrepreneurial non-profit organization, social cooperative, community development enterprise, and social business. The various types are in accordance with the social-culture of the Indonesian people. It shows there are many parties that can be invited to cooperate in creating the startups. Through collaborating with stakeholders can realize the seeds of social entrepreneurship on campus and promote innovation for sustainable development.

Related to the mediating variable, the social entrepreneurship self-efficacy is able to link the empathy to the PSE. Although at the low level, this relation is appropriate with (Ayob et al., 2013) which emphasized the empathy positively impacts to perceived feasibility. According to (Shapero and Sokol, 1982) stated "perceived feasibility is how an individual believes in his or her capability of starting entrepreneurial venture". This variable is identical to the perceived behavioral control in TPB, or similar to perceived socialefficacy. (Likewise and Hockerts, 2017); (Ip et al., 2017) which found the direct effect the empathy to the intention. Empathy is a natural ability to understand the feelings of others so that this outbreak fosters a sense of solidarity with others. Accordance to (Mair and Martí, 2006) empathy is related to the context of helping behavior. Actually, the pandemic inspires people to help each other so that the feeling triggers to foster self-confidence among students and form intention in the social entrepreneurship. Aligning with a social entrepreneurial perspective, this mediation effect proves the role of self-efficacy to form social propensity through being an empathy. 
According to (Van Bavel et al., 2020) stated that in facing the pandemic of Covid-19, the norms of pro-social behavior are more effective when combined with expectations of social approval and modeled by group members who are central in social networking. Because of this statement, the existence of social entrepreneurs takes the role of social support for people during the pandemic. Indeed, social behavior accommodates the scarcity of medical supplies, in particular providing masks, hazmat suits, sanitizer products, social education, charity auction, and healthy live campaign for people. Besides that, in the economic aspect, the social solidarity among social entrepreneurs initiate crowdfunding to fund the micro, small and medium enterprises which are directly impacted during this pandemic. In this situation, empathy is able to shift the individual characters into a collective that is a care with this outbreak.

Moreover, the social entrepreneurship self-efficacy is able to link the moral obligation to PSE. Moral obligation is an expression of a sense of responsibility towards social problems so that by having this character someone will be attracted by humanity solutions. In fact, the philanthropic tradition also supports the formation of moral responsibility for community problems. The philanthropic activity aims to provide services to the public. Accordingly, the social entrepreneur prioritizes social value higher than the economic value (Mair and Martí, 2006). The Covid-19 pandemic carries moral responsibility so that it fosters self-confidence in students so that this responsibility has a positive effect on social entrepreneurial intention. Even though, (Hockerts, 2017); (Ip et al., 2017) Found the direct impacts between moral obligations to the intention. However, this study places the mediating effect through self-efficacy. For beginners or entrepreneurial students, the moral obligation will drive self-confidence so that they feel able to engage in social enterprises. Under the condition, the moral obligation can turn the behavior of students to be careful with social problems, specifically in the pandemic times.

Finally, the social entrepreneurship self-efficacy is able to link the prior experience to PSE. In general, prior experience greatly influences business success. (Hockerts, 2017) stated prior experience related to social problems is regarded as practical experience in working with social-sector organizations. With experience, someone will get used to deal with social problems or collaborating with social institutions. Further, the experience in managing a business during a pandemic can strengthen their self-efficacy and become more interested in social ventures. This ability increases self-confidence among students so that it is able to improve their intention on social entrepreneurship. In line with the entrepreneurial potential model (Krueger, 1993; Krueger JR et al., 2000), that the previous experience as one of the exogenous factors which influence the perceived social norms and self-efficacy, then affects the perceived feasibility and eventually form intentions. Understanding of intention can be studied through (Shapero and Sokol, 1982), that one of the antecedents of entrepreneurial intention is perceived feasibility. It is relevant to the entrepreneurial event model. Based on the results, the mediation effect was proven in understanding the role of self-efficacy to improve prior experience toward social propensity. The idea of collaboration in the previous section can be used as an opportunity to improve students' experience in the social field so as to increase their confidence in building social entrepreneurship. Thus, these ideas can increase self-efficacy or perceived behavioral control among students so that their mindset meet to form the propensity on social entrepreneurship.

Globally, social entrepreneurship have relevance to the program of sustainable 
development. The role of social entrepreneurs directly contributes to the SDGs. Referring to WCED, (1987), defined "the sustainability is a development that meets the need of the present without compromising the ability of future generations to meet their own needs". It is a commitment to provide the social welfare between generations. SDGs relate to the triple bottom lines consist of environmental, social, and economic's aspects. Hence, the social entrepreneur has two portions to drive overcoming the problem of nature and social environment. As an effort to achieve sustainability, previously the United Nations declared the MDGs in 2000 which arranged eight goals including health, education, gender equality, and environmental issues. Social entrepreneurs have a role in dealing with eradicating poverty, achieving gender equality, environmental sustainability, and helping to create a global partnership. Related to the disease, HIV/AIDS was the target of the MDGs until 2015 where the social role of entrepreneurs and NGOs is meaningful in overcoming the problem.

Nowadays in 2020, the global community is facing a global pandemic of Covid-19 that is more devastating than HIV, SARS, MERS, or Ebola. For these reasons, the role of social entrepreneurs is most important and noble to jointly overcome the outbreak. Therefore, the institutional commitment in the learning program of social entrepreneurship is a part of the global commitment toward sustainable development so that it will become a sustainable advantage for institutions in the future. If this idea can be realized it means that there will be alignment with the goals of the global community and the goals of the educational institute.

\section{CONCLUSION}

This research proves the significant relationship among constructs. Related to the TPB, the social entrepreneurial self-efficacy and perceived social support impact significantly to PSE. It proves the mediating effect of social entrepreneurial self-efficacy to link empathy, moral obligation, and prior experience to PSE. This pandemic is a trigger for students, thereby they are more interested in social enterprises or other kinds of SE. Although, currently only focused on social action, but most of the students have the perspective that someday after a new normal situation will be more involved in social organizations or will share social values in business. The desire is intended so that entrepreneurs can contribute to coping with social problems. Furthermore, this result proves the effects of psychological aspects in fostering the propensity on SE in the outbreak background. This mindset is potential forms the pro-social behavior among students.

It is a mechanism when understanding social entrepreneurial education, thus the avenue for the next studies can develop pro-social behavior during the outbreak involving the construct of social-cultural in Indonesian society. The second plan can engage the practitioners of SE as a respondent or source person. Based on both of the respondents, it can be investigated to what extent a construct is perceived by entrepreneurship students and real entrepreneurs. The institution leaders can use the outcomes of the study to complement the entrepreneurship education model so that the orientation of education is able to align with the economic goals and social values in building business startups. 


\section{REFERENCES}

Ajzen, I. (1991). The Theory of Planned Behavior. Organizational Behavior and Human Decision Processes, 50, 179-211.

Ajzen, I. (2002). Perceived Behavioral Control, Self-Efficacy, Locus of Control, and the Theory of Planned Behavior. Journal of Applied Social Psychology., 32(4), 665-83.

Aure, P. A. P. (2018). Exploring the Social Entrepreneurial Intentions of Senior High School and College Students in a Philipine University: A PLS-SEM Approach. Journal of Legal, Ethical and Regulatory Issues, 21(2), 1-11.

Aure, P. A. P., Dui, R. P., Jimenez, S. V., Daradar, D. D., Gutierrez, A. N. A., Blasa, A. C., and Sy-Changco, J. (2019). Understanding Social Entrepreneurial Intention Through Social Cognitive Career Theory: a Partial Least Squares Structural Equation Modelling Approach. Organizations and Markets in Emerging Economies, 10(1), 92110. https://doi.org/10.15388/omee.2019.10.00005.

Austin, J. E. (2006). Three Avenues for Social Entrepreneurship Research. In J. Mair, J. Robinson, \& K. Hockerts (Eds.), Social Entrepreneurship (pp. 22-33). London: Palgrave Macmillan UK. https://doi.org/10.1057/9780230625655_3.

Ayob, N., Yap, C. S., Sapuan, D. A., and Rashid, M. Z. A. (2013). Social Entrepreneurial Intention among Business Undergraduates: An Emerging Economy Perspective. Gadjah Mada International Journal of Business, 15(3), 249-267. https://doi.org/10.22146/gamaijb.5470.

Bird, B. (1988). Implementing Entrepreneurial Ideas: The Case for Intention. The Academy of Management Review, 13(3), 442-453. https://doi.org/10.2307/258091.

British Council, and UNESCAP. (2018). Developing an Inclusive and Creative Economy: The State of Social Enterprise in Indonesia. Jakarta: British Council Indonesia.

Chinchilla, A., and Garcia, M. (2017). Social Entrepreneurship Intention: Mindfulness Towards a Duality of Objectives. Humanistic Management Journal, 1, 205-214. https://doi.org/10.1007/s41463-016-0013-3.

Cho, A. H. (2006). Politics, Values and Social Entrepreneurship: A Critical Appraisal. In J. Mair, J. Robinson, \& K. Hockerts (Eds.), Social Entrepreneurship (pp. 34-56). London: Palgrave Macmillan UK. https://doi.org/10.1057/9780230625655_4.

Dacin, M. T., Dacin, P. A., and Tracey, P. (2011). Social Entrepreneurship: A Critique and Future Directions. Organization Science, 22(5), 1203-1213. https://doi.org/10.1287/orsc.1100.0620.

De Groot, J. I. M., and Steg, L. (2009). Morality and Prosocial Behavior: The Role of Awareness, Responsibility, and Norms in the Norm Activation Model. The Journal of Social Psychology, 149(4), 425-449. https://doi.org/10.3200/SOCP.149.4.425-449.

Decety, J., and Jackson, P. L. (2004). The Functional Architecture of Human Empathy. Behavioral and Cognitive Neuroscience Reviews, 3(2), 71-100. https://doi.org/10.1177/1534582304267187.

Dees, J. G. (1998). The Meaning of Social Entrepreneurship. Kansas. Retrieved from https://community-wealth.org/content/meaning-social-entrepreneurship.

Defourny, J., and Kim, S.-Y. (2011). Emerging Models of Social Enterprise in Eastern Asia: A Cross-Country Analysis. Social Enterprise Journal, 7(1), 86-111. https://doi.org/10.1108/17508611111130176.

Haines, R., Street, M., and Haines, D. (2008). The Influence of Perceived Importance of an 
Ethical Issue on Moral Judgment, Moral Obligation, and Moral Intent. Journal of Business Ethics, 81(2), 387-399. https://doi.org/10.1007/s10551-007-9502-5.

Henseler, J., Ringle, C. M., and Sinkovics, R. R. (2009). The Use of Partial Least Squares Path Modeling in International Marketing. In New Challenges to International Marketing Advances in International Marketing (Vol. 20, pp. 277-319). Emerald Group Publishing Limited. https://doi.org/10.1108/S1474-7979(2009)0000020014.

Hockerts, K. (2006). Entrepreneurial Opportunity in Social Purpose Business Ventures. In J. Mair, J. Robinson, \& K. Hockerts (Eds.), Social Entrepreneurship (pp. 142-154). London: Palgrave Macmillan UK. https://doi.org/10.1057/9780230625655_10.

Hockerts, K. (2017). Determinants of Social Entrepreneurial Intentions. Entrepreneurship Theory and Practice, 41(1), 105-130. https://doi.org/10.1111/etap.12171.

Ip, C. Y., Wu, S.-C., Liu, H.-C., and Liang, C. (2017). Revisiting the Antecedents of Social Entrepreneurial Intentions in Hong Kong. International Journal of Educational Psychology, 6(3), 301-323. https://doi.org/10.17583/ijep.2017.2835.

Koe, W.-L., Omar, R., and Majid, I. A. (2014). Factors Associated with Propensity for Sustainable Entrepreneurship. Procedia - Social and Behavioral Sciences, 130, 6574. https://doi.org/10.1016/j.sbspro.2014.04.009.

Koe, W.-L., Omar, R., and Sa'ari, J. R. (2015). Factors Influencing Propensity to Sustainable Entrepreneurship of SMEs in Malaysia. Procedia - Social and Behavioral Sciences, 172, 570-577. https://doi.org/10.1016/j.sbspro.2015.01.404.

Krueger, N. F. (1993). The Impact of Prior Entrepreneurial Exposure on Perceptions of New Venture Feasibility and Desirability. Entrepreneurship Theory and Practice, 18(1), 5-21. https://doi.org/10.1177/104225879301800101.

Krueger JR, N. F., Reilly, M. D., and Carsrud, A. L. (2000). Competing Models of Entrepreneurial Intentions. Journal of Business Venturing, 15, 411-432.

Mair, J., and Martí, I. (2006). Social Entrepreneurship Research: A Source of Explanation, Prediction, and Delight. Journal of World Business, 41, 36-44. https://doi.org/10.1016/j.jwb.2005.09.002.

Mair, J., and Noboa, E. (2006). Social Entrepreneurship: How Intentions to Create a Social Venture are Formed. In J. Mair, J. Robinson, \& K. Hockerts (Eds.), Social Entrepreneurship (pp. 121-135). London: Palgrave Macmillan UK. https://doi.org/10.1057/9780230625655_8.

McDonald, N. L., and Messinger, D. S. (2011). The Development of Empathy: How, When, and Why. In A. Acerbi, J. A. Lombo, \& J. . Sanguineti (Eds.), Free will, Emotions, and Moral Actions: Philosophy and Neuroscience in Dialogue (pp. 1-36). Miami: University of Miami, Department of Psychology. Retrieved from http://local.psy.miami.edu/faculty/dmessinger/c_c/rsrcs/rdgs/emot/McDonaldMessinger_Empathy Development.pdf.

Peredo, A. M., and McLean, M. (2006). Social Entrepreneurship: A Critical Review of the Concept. Journal of World Business, 41, 56-65. https://doi.org/10.1016/j.jwb.2005.10.007.

Pihie, Z. A. L., Bagheri, A., and Sani, Z. H. A. (2013). Knowledge of Cognition and Entrepreneurial Intentions: Implications for Learning Entrepreneurship in Public and Private Universities. Procedia - Social and Behavioral Sciences, 97, 174-181. https://doi.org/10.1016/j.sbspro.2013.10.219.

Pratono, A. H., Pramudija, P., and Sutanti, A. (2016). Social Enterprise in Indonesia: 
Emerging Models under Transition Government (International Comparative Social Enterprose Models (ICSEM) No. 36). ICSEM Working Paper. Belgium. Retrieved from http://www.jolkona.org/social-enterprise-in-indonesia/.

Robinson, J. (2006). Navigating Social and Institutional Barriers to Markets: How Social Entrepreneurs Identify and Evaluate Opportunities. In J. Mair, J. Robinson, \& K. Hockerts (Eds.), Social Entrepreneurship (pp. 95-120). London: Palgrave Macmillan UK. https://doi.org/10.1057/9780230625655_7.

Shapero, A., and Sokol, L. (1982). Social Dimensions of Entrepreneurship. In C. A. Kent, D. L. Sexton, \& K. H. Vesper (Eds.), The Encyclopedia of Entrepreneurship (pp. 7290). Prentice-Hall.

Shaw, E., and Carter, S. (2007). Social Entrepreneurship: Theoretical Antecedents and Empirical Analysis of Entrepreneurial Process and Outcomes. Journal of Small Business and Enterprise Development, 14(3), 418-434. https://doi.org/10.1108/14626000710773529.

Shumate, M., Atouba, Y., Cooper, K. R., and Pilny, A. (2014). Two Paths Diverged: Examining the Antecedents to Social Entrepreneurship. Management Communication Quarterly, 28(3), 404-421. https://doi.org/10.1177/0893318914538561.

Smith, A. (2006). Cognitive Empathy and Emotional Empathy in Human Behavior and Evolution. The Psychological Record, 56, 3-21. https://doi.org/10.1007/BF03395534

Tiwari, P., Bhat, A. K., and Tikoria, J. (2017). An Empirical Analysis of the Factors Affecting Social Entrepreneurial Intentions. Journal of Global Entrepreneurship Research, 7(9), 1-25. https://doi.org/10.1186/s40497-017-0067-1.

Turker, D., and Sonmez Selcuk, S. (2009). Which Factors Affect Entrepreneurial Intention of University Students? Journal of European Industrial Training, 33(2), 142-159. https://doi.org/10.1108/03090590910939049.

Van Bavel, J. J., Baicker, K., Boggio, P. S., Capraro, V., Cichocka, A., Cikara, M., Willer, R. (2020). COVID-19 pandemic response. Nature Human Behaviour, 1-12. https://doi.org/10.1038/s41562-020-0884-z.

WCED, U. (1987). Development and International Economic Co-Operation: Environment. England. 